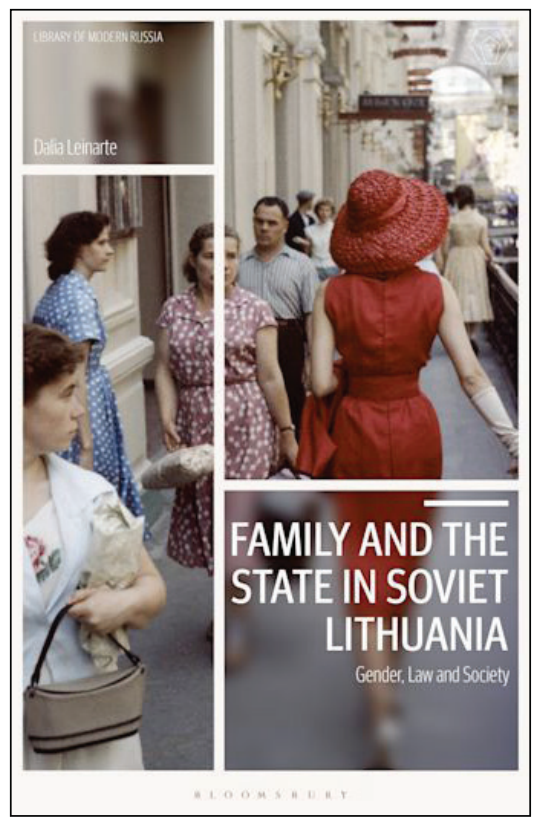

\section{Family and the State in Soviet Lithuania: Gender, Law and Society}

\author{
Dalia Leinarte \\ London \& New York: Bloomsbury Academic \\ 2021 \\ 226 sider. ISBN 9781350136090
}

Omtalt af Lars Johannsen [ph.d., lektor, Institut for Statskundskab, Aarhus Universitet, johannsen@ps.au.dk]

I 1992 flyttede jeg til Litauen - en tid med store omstillinger. Landet var lige blevet uafhængigt, frie valg skulle gennemføres, og økonomien var i frit fald med varemangel og hyperinflation. I gadebilledet så jeg mange unge, nyligt fraskilte enlige mødre, alkoholen var allestedsnærværende, og boligforholdene dårlige. Det var kvinder, som stod i kø efter helt almindelige forbrugsgoder. Samfundet syntes patriarkalsk i tale, opførsel og konsekvens. Jeg undrede mig: Var ligestilling ikke en af kommunismens bedrifter?

Jeg oplevede afslutningen på den periode, som Leinarte undersøger i sin nye bog. Historien udfolder sig fra den sovjetiske besættelse i 1940 til midt i 1980'erne, men vægten ligger på den første halvdel af perioden. Hvad bestod den sovjetiske ligestillingslov, familiepolitik og ideologi af? Hvilke konsekvenser fik det for familien og især kvinder? Bogen argumenterer for, at staten regulerede det meste af familiens livsvilkår og efterlod meget lidt tid til individet og familien. Familien var ikke et reservoir af frihed - en modstand mod besættelsen og den kommunistiske undertrykkelse i Litauen. Et argument, som ellers er betonet i den nyere baltiske historieskrivning.

Bogen består, ud over introduktion og konklusion, af fire kapitler. Det første kapitel omhandler familiepolitikken. Det andet analyserer ægteskab og skilsmisse. Det tredje handler om barsel og børnepasning, og det sidste om boligforhold og husholdningen. Introduktionen beskriver de enorme forandringer, som besættelse, holocaust, krigens tab af menneskeliv og ejendom samt deportationer medførte. 
Samtidig blev sovjetisk lovgivning i Stalin-perioden kopieret og implementeret, og planøkonomien indført, og dertil skal lægges et totalitært system og propaganda.

Første kapitel analyserer sovjetisk familie- og ligestillingspolitik. Ved den første indlemmelse i 1940 bliver lovgivningsgrundlaget direkte oversat fra det tilsvarende sovjetiske. Efter krigen tvinges kvinder til at blive, og bliver, en del af arbejdsstyrken. Nøgleordet er her "tvinges». Kvinder rekrutteres til såkaldte frivillige brigader i genopbygningen og skal deltage $i$, hvad der bedst kan beskrives som genopdragelsesmøder. Propagandaen udstiller hjemmegående som parasitter, og de mister retten til offentlige goder. Der indføres barselsorlov, men støtten til enlige med børn har ikke et tilstrækkeligt omfang og forsvinder i korruption. Politikken får umiddelbar effekt. I midten af 1960'erne udgør kvinder 49 procent af arbejdsstyrken, og allerede i midten af 1950'erne er der for eksempel flest kvindelige læger, men ligestillingen er hul. Sprogligt og i praksis opnås der ikke megen indflydelse. Sammenlignet med mænd får kvinder kun to tredjedele i løn, og med arbejde inden- og udenfor hjemmet har kvinder ikke meget tid til sig selv.

I andet kapitel analyseres ægteskabet og det voksende antal skilsmisser. I den katolske mellemkrigstid var mulighederne for skilsmisse få, men var ægteskabet nu ikke civilt, frem for kirkeligt, registreret, fik det konsekvenser for bodelingen. Det gjaldt ikke mindst for, hvem der overtog lejemålet, og hvem der blev bopælsforælder. I praksis betød boligmanglen ofte, at nyligt fraskilte måtte forblive boende sammen og til tider endda sammen med den tidligere ægtefælles nye partner og forældre. Men modsat den katolske mellemkrigstid havde alle nu ret til skilsmisse. Der afholdtes bekendelsesmøder om ægteskabelige forhold, og retlige afgørelser af skilsmisser var offentlige. Her kunde alle snage i ægteskabelige problemer. Leinartes undersøgelse viser, at vold mod ægtefællen skete på daglig basis, og alkohol spillede en stor rolle.

Andet kapitel har et afsnit om den sovjetiske forståelse af sex, kærlighed og familie fra Den Russiske Revolution til 1980. I begyndelsen var kommunismen åben for seksuelle forhold og eksperimenter, men blev hurtigt konservativ. Seksuel attraktion og romance kan føre til ægteskab, men ægte kærlighed lå i et ægteskab, hvor kvinder føder og opdrager børn til den kommunistiske udvikling. Familiepolitikken og boligforhold førte til stadigt tidligere indgåelse af ægteskab. Fra 1946 til 1975 faldt gennemsnitsalderen ved giftermål for kvinder fra 25 til 22 år. Forskellen var endnu større for mænd. Her faldt den fra 30 til 23 år. Mange blev hurtigt skilt - heraf de unge mødre, jeg mødte.

Tredje kapitel fokuserer på børnepasning og barsel. Kun langsomt udvikledes pasningsmuligheder i byerne, men selvom fødselsraten faldt var behovet for pasning større. I byerne sås fænomenet "nøglebørn", det vil sige børn, som kendtes ved at have nøglen til hoveddøren i en snor om halsen, og som var overladt til sig selv det meste af dagen.

Fjerde kapitel sætter fokus på boligforholdene. Fra begyndelsen var landet hærget af 2. Verdenskrig, og boligmanglen stor, men boligmanglen steg yderligere i takt med urbaniseringen. Der kunne ikke bygges boliger hurtigt nok, heller ikke selvom 
der opstod hele nye distrikter med betonblokke. Et interessant afsnit er, at kvinderne, som ikke kunne udnytte kontakter i partiet, for eksempelvis at skaffe sig en bedre bolig skrev bønskrifter eller klager til embedsmænd eller redaktører af aviser. De kunne så anvende deres kontakter i partiet for at hjælpe kvinderne. Nogle hjalp nok af ægte interesse og medlidenhed, men intet er gratis. Til gengæld for tjenesten afgives personlig loyalitet, som embedsmændene, journalisterne og redaktørerne kan omveksle til større politisk indflydelse. Hvorvidt det kun var kvinder, som skrev bønskrifter, skriver Leinarte ikke om, men hun følger en årelang korrespondance mellem en kvinde med fysiske handicap og en journalist på avisen Tiesa, den litauiske udgave af Pravda. Her vises både virkemidler og skrøbeligheden i det blat-forhold, det vil sige de uformelle nepotistiske relationer, som etableres. "Bønskrifterne» er et hidtil ukendt fænomen for mig. Det at kvinderne turde klage, kan ses som en form for politisk deltagelse i Sovjetunionen - noget, Leinarte ikke reflekterer over i sin bog.

Leinarte konkluderer, at den sovjetiske ligestillingspolitik ikke stræbte efter lige rettigheder og ophøret af diskrimination af kvinder. I ligestillingens navn, med tvang og trusler, blev kvinder en del af arbejdsstyrken. Der var fastlagte kvoter for deltagelse i beslutningsorganer, men regimet ændrede aldrig på patriarkalske stereotyper. Opfattelsen af kvindens rolle i hjemmet og børneopdragelse forandrede sig ikke.

Leinartes bog er et vægtigt bidrag. Den er baseret på et imponerende kildemateriale af avisartikler, læserbreve, bønskrifter til myndigheder og retsudskrifter. Dertil suppleres med en række interviews, som Leinarte har gennemført over en 10-årig periode. Enhver områdespecialist, kønsforsker eller retssociolog bliver beriget, men selv trænede læsere vil ofte miste overblikket i de mange små skæbnehistorier, ikke mindst fordi der springes frem og tilbage i tid. Det viser sig også vanskeligt at fokusere på de enkelte emner for hvert kapitel uden at tage hul på det næste. Der savnes derfor bedre introduktioner til hvert kapitel for at skabe overblik. En strammere styring og visuelle virkemidler som for eksempel tidslinjer ville have hjulpet læseren. Selvom historierne er en styrke, så vil Leinarte fortælle for meget.

Bogen undersøger udviklingen i en sovjetrepublik - Litauen, og selvom der trækkes på materiale fra andre dele af Sovjetunionen, må spørgsmålet stilles, om analysen kan generalises til de øvrige republikker eller er bundet til et katolsk, krigshærget landbrugssamfund underlagt sovjetisk industrialisering og styre. Udviklingen perspektiveres heller ikke til den tilsvarende periode i Vesten. Det er ikke hendes anliggende, men bogen næsten skriger på en refleksion. Også i Vesten indtog kvinderne arbejdsmarkedet, og antallet af skilsmisser steg. "Nøglebørn« er et genkendeligt begreb, og trods lovgivning tjener kvinder stadig mindre end mænd og varetager flere huslige opgaver.

Leinarte giver svar på min undren for 30 år siden og mit møde med de unge enlige kvinder. Mon den nye tid med uafhængighed, markedsøkonomi og demokrati vil føre til ligestilling - eller overlever patriarkalske værdier endnu en gang? 